\title{
An analysis of the deinstitutionalization of inflation-adjusted accounting practices in Brazilian companies
}

Amaury José Rezende - Brazil

Ph.D. in Accountancy and Controllership, University of São Paulo-School of Economics, Business Administration and Accountancy, Brazil Professor, University of São Paulo at Ribeirão Preto School of Economics, Business Administration and Accountancy, Brazil

E-mail: amauryj@usp.br

Reinaldo Guerreiro - Brazil

Ph.D. in Accountancy and Controllership, University of São Paulo School of Economics, Business Administration and Accountancy, Brazil

Full Professor, University of São Paulo School of Economics, Business Administration and Accountancy, Brazil

E-mail: reiguerr@usp.br

Flávia Zóboli Dalmácio - Brazil

Ph.D. in Accountancy from University of São Paulo School of Economics, Business Administration and Accountancy, Brazil

Professor at University of São Paulo School of Economics, Business Administration and Accountancy, Brazil

E-mail: flaviazd@usp.br

Received on 11.17. 2010 - Accepted on 1.19.2011 - $3^{\text {rd }}$ version on 3.23.2011

\section{ABSTRACT}

This article aims to analyze the deinstitutionalization of the inflation-adjustment accounting practices used by large Brazilian companies. The theoretical assumptions used were based on institutional theory, which provides a sociological interpretation of human behavior that recognizes the phenomenon of limited rationality and the political character of social action. Analyses were based on the empirical approach that was proposed by Oliver (1992). The research strategy consisted of questionnaires and interviews conducted in a population of 118 large Brazilian companies from Exame Magazine's list of the 500 largest companies. The primary respondents were accountants and controllers. Factor analysis, one-way ANOVA and the Kruskal-Wallis test were conducted using the approach proposed by Oliver (1992), and the research included 22 variables comprising 12 constructs and 6 qualitative hypotheses regarding the pressures that motivate the deinstitutionalization of inflationadjusted accounting practices. Therefore, with regard to the constructs assessed, emphasis was placed on identifying the political pressures (the environment) and the functional pressures in both the organizational and environmental dimensions. However, the social pressures did not prove to be significant. We conclude that the process of deinstitutionalization results from a distinct combination of institutional factors, and these results are consistent with the findings from research conducted in the US market and in the UK.

Keywords: Deinstitutionalization. Inflation adjustment. Institutional theory. Decoupling of accounting information. 


\section{INTRODUCTION}

In an inflationary environment, any accounting figures that are calculated using the method of historical cost based on value cannot be translated to reflect the dynamics of the external economic environment, thus causing a loss in relevance (utility), comparability and materiality of the accounting information, i.e., the accounting information loses legitimacy to its associated stakeholders.

The practice of accounting restatement represents an institutional control system that aims to measure the effects of inflation on the accounting figures that are reported to the market and other stakeholders in a given period. With regard to the institution of formal control systems, Collier (2005, p. 337) criticized the conceptual framework proposed by Simons (1995) and Ferreira and Otley (2005) because it pays little attention to the relationship between belief systems and the forms of control used by organizations. Collier also emphasized that the interaction between formal and social systems of control needs to be investigated.

According to Oliver (1991), legitimacy can be intentionally sought and institutional standards can be subject to acceptance or rejection by organizations. In this context, the desire to regain the accounting information legitimacy that was lost due to the highly volatile economy led to several actions being taken - sometimes coercively, sometimes normatively - within the Brazilian institutional environment. These actions were imposed to correct for the distortions caused by inflation and to rescue the legitimacy of the accounting information for its users.

Thus, government regulatory and inspection agencies (the Federal Revenue Secretariat of Brazil and the Securities Commission) coercively instituted Laws and Prescriptive Instructions that required the various organizational actors to adhere to a homogenized set of accounting standards of conduct (through the adoption of an accounting restatement model), i.e., organizations with similar organizational characteristics, such as opting for the taxation of actual profit, having shares traded on stock exchanges and/or being included in a given economic sector, would have to adhere to the same accounting standard. This requirement created homogenous standard accounting "practices" under a scenario of high levels of inflation, where the maintenance of this practice was supported by the strength of the coercive and prescriptive mechanisms that institutionalized the indexation model that was used by companies and that lasted for decades.

However, the laws and rules that had created standardized homogeneous accounting in the organizational field lost their strength with the establishment of the "Real Plan" economic plan in 1994, the goal of which was to control the high levels of inflation and achieve economic stability. In this context, there was an inversion of values and of the legitimacy of the practices institutionalized during the periods of high inflation. The use of accounting restatement practices was considered to be a legitimate standard of conduct and to be within the precepts of the instituted economic plan. Restatement was perceived not only as a practice that could correct for the effects of inflation on accounting figures but also as one the continuing presence of which in the accounting arena encouraged the persistence of inflation because the publication of adjusted financial statements maintained inflationary memory in society (Cardoso, 2009). Thus, the mandatory nature of the institutionalized accounting restatement practices was voided, and a law was established that prohibited the publication of joint adjusted statements and that required that these accounts be produced for management and only be published as an additional statement.

A movement to abandon monetary correction practices was thus initiated, and a procedure that had been institutionalized and incorporated into the habits and routines of the organization began to be phased out through prescriptive and coercive pressures. Later, an adjustment was made to the "Law," making indexation optional for companies; organizations were allowed to continue using accounting restatement practices if they wished, but the financial statements would have to be published separately and not jointly, as was previously followed, with the figures for assets, liabilities, revenues, costs and expenses in parallel columns (with and without corrections).

In an analysis of the 500 companies that are classified as bigger and better, according to the database of Exame - Best and Biggest (Exame - Melhores e Maiores) maintained by the Institute of Accounting, Actuarial and Financial Research (Fundação Instituto de Pesquisas Contábeis, Atuariais e Financeiras [FIPECAFI]), in the year following the establishment of the Real Plan, over $50 \%$ of these companies did not publish the adjusted information, although that does not mean that the practice was not being used for internal decision-making in these organizations. Approximately 212 companies continued to publish the adjusted information between 1995 and 2006. These differences could indicate that the perception of the value and legitimacy of this practice is different between actors that participate in the same organizational field. It was found that movement away from the practice did not occur in a radical and complete form in all companies. Large companies that are considered leaders in their sectors continued to use indexation, both in internal decision-making processes and in the publication of additional information. However, the value and legitimacy of this practice began to deteriorate for the managers and stakeholders.

This behavior can be observed in the scenario described by Lukka (2007, p. 98), in which formal rules legitimize the existence of an organization and allow for informal routines. In turn, these informal routines act 
as "protection" for the system, legitimizing the current systems of formal rules and protecting interests from the pressure to change.

Relief from the pressure to change has led some organizations to informally maintain routines, and this maintenance can be viewed as a short-term solution that causes these organizations to postpone functional adaptations for a long time compared with other organizations that participate in the same organizational field (the capital market).

Given the influence of the environment and the mass of institutional factors and interests involved that impact the legitimacy of actions, for this research, it was decided to choose an institutional approach with theoretical support because using this type of approach permits an analysis of the effects of the role of institutions, which act by accelerating or delaying the development, implementation or abandonment of standards and practices.

The new institutional sociology (NIS) theory seeks to explain why organizations in particular areas tend to become similar in terms of their behaviors, routines and structures. In this approach, the theorists distinguish between two environments: the technical and the institutional. In the technical environment, the actors are concerned with achieving technical efficiency in the organization's operations. In the institutional environment, the actors are concerned with the need to embrace/adopt rules and social norms and to meet the expectations of those outside of the organization. In both dimensions, the organizations tend to appear legitimate before their shareholders and stakeholders, thus ensuring access to the resources that are necessary for survival (DiMaggio \& Powell, 1983; Meyer \& Rowan, 1991; Scapens, 2006).

Machado-da-Silva, Fonseca and Crubellate (2005) argued that this approach is used to understand the historicity and the recursion of structures and practices from an institutional perspective. They also noted that one of the contributions that neoinstitutional theory makes to organizational studies is that it emphasizes the influence of the environment, which, along with legitimacy and isomorphism, is a vital component of organizational survival.

In this context, this article aims to identify the pressures that contributed to the deinstitutionalization process associated with the accounting restatement practices because many companies stopped using them. Several research questions are raised, such as the following: Why do companies no longer use this practice? Why do some companies still produce and publish adjusted information? Why do other companies not produce and publish adjusted information in view of its relevance?

Scapens (2006, p. 27) claimed that the systematic pressures that influence and shape the accounting practices in organizations are due to economic pressures, derived from new institutional economics (NIE) theory, that induce organizations to seek greater technical efficiency in their operations. These systematic pressures are also caused by pressures for legitimacy (NIS) that are related to the search for actions that cause the organization to conform to the expectations of its stakeholders. Furthermore, the pressures can be both external and internal in nature, and the process of change in management accounting practices is viewed as an evolutionary path.

An analysis model that is based on the assumptions of deinstitutionalization (Oliver, 1991, 1992) was constructed from the observed gradual abandonment of these accounting restatement practices in organizations and was used to empirically identify the pressures that led to the erosion and abandonment of accounting restatement practices in major Brazilian companies.

\section{THEORETICAL FRAMEWORK}

\subsection{Accounting practices as a tool for} legitimizing actions and strategies

New institutionalists believe that people live in a world that is socially constructed and permeated by rules and meanings. Much of an actor's activity is neither conscious nor intentional; it is undertaken unconsciously, as a matter of routine. Meyer and Rowan (1991) argued that there is a dichotomy between the pursuit of efficiency through technical activities and the search for legitimacy through inclusion in an institutionalized environment. These authors argued that the formal structures of many organizations in a post-industrial society dramatically reflect the myths of their institutional environments instead of the demands of their operating activities. Thus, the institutionalized rules are classifications that are constructed within society, such as typifications or reciprocal interpretations, and are taken for granted or maintained by public opinion or force of law (Meyer
\& Rowan, 1991). Because organizations have often incorporated a variety of rational procedures, processes and rules in their formal structure, accounting represents a formal system (Carruthers, 1995).

Meyer and Rowan (1991) noted that the main reason for adopting a formal structure should normally be the search for greater efficiency in organizational decisions and the achievement of better results. In fact, rationalized elements are incorporated because they maintain appearances. In other words, the elements represent the search for legitimacy through the perception of conformity, i.e., standards are accepted within a system (Suchman, 1995). Continuing this reasoning, they added that the organizations that incorporate rational, socially legitimated elements within their formal structures maximize their legitimacy and increase their resources and their ability to survive. Myths are taken for 
granted and viewed as legitimate, independent of any assessment of their impact on operating results. Myths help to confer legitimacy on the organization. Moreover, modern Western societies favor a particular form of rationality; therefore, the organizations that operate within a cultural context will acquire more legitimacy if they can emulate or symbolically reproduce that rationality (Carruthers, 1995). In this line of reasoning, inflation is a product of social conduct with a shared meaning for actors, i.e., it represents both individual and collective subjectivity. In his research, Carruthers (1995) discussed the concept of decoupling, extracted from the arguments of Meyer and Rowan (1991). The formal organizational structure, with its highly rationalized appearance, is dissociated (or decoupled) from real organizational practice.

Kury (2007) noted that the behavior of managers can be motivated not only by conflicts of interest (agency-based motivations of self-interest) but also from the pressure for legitimacy, such as regulatory, normative and culturalcognitive pressures. Given the central logic that the maintenance of restatement practices applied to accounting figures during a particular period can produce a situational reality of "maximizing shareholder value" that is different than that expected by the "capital market," analyzing the pressures that occur within the institutional field provides an interesting context for exploring the use of this practice as a decoupled behavior.

The adoption of certain accounting practices or accounting systems during a certain period as a formal structure represents the above concept well. Such a structure can be simply viewed as a formal ceremonial structure or as a type of symbol used to create a good impression; however, in reality, it does not provide the true facts. Carruthers (1995) explained that significant decoupling can be attributed to the spread of rationalized procedures and cultural rules, rather than technical processes, which are not able to improve organizational performance. The procedures and rules can, however, improve the appearance of the organization, creating an image of rational choice that is not based on reality.

Meyer and Rowan (1991) reported that organizational success depends on factors other than the efficient coordination and control of productive activities. In this context, Chua (1986) stated that the purpose of accounting is to help people make highly rational decisions because it represents a set of procedures that enables the creation and processing of information that, in turn, helps business people choose more profitable actions (Istvan \& Avery, 1979; Davidson, Sticckney \& Weil, 1988). The decoupling of a new accounting practice, while having little or no effect on corporate operations, would, according to new institutionalism, justify the actions of the manager who used a rational process and thus improve the company's image with its investors (Carruthers, 1995).

Mainstream accounting theory considers that accounts can help produce better decisions. Accordingly, the application of accounting rules will generate in- formation that will inform decision-makers about the current situation and help them to choose the best strategies. However, if accounts are being used to justify decisions rather than to make good decisions, we can say that the rationalization of accounting is dissociated or decoupled from reality (Carruthers, 1995). As the financial accounts can be manipulated or can be viewed only as a kind of symbol to create a good impression, their credibility, neutrality, impartiality and objectivity lose effectiveness in the evaluation of organizational performance.

In this context, in his research, Kury (2007) observed that when organizational performance (profit) does not meet the standard of legitimacy, there is a gap between the structure and the activity. In this case, the accounts are decoupled from the results by profit managing. It becomes difficult to maintain appearances because the decoupling of the formal structure from the actual organizational practice becomes too transparent. However, decoupling in financial accounts is more likely to be accepted by people who do not have accounting expertise, who are more likely to be "deceived" and believe in a rational appearance and who are less likely to discover the degree of dissociation (Carruthers, 1995).

When accounting rules are used to manipulate the official measures of profit, decoupling can endanger the organizational appearance. For example, a corporation can inflate its profits in favor of the shareholders or present an inaccurate picture of their unionized workers. Because accounts can mean different things to different audiences depending on how they are used (Carruthers, 1995), accounting restatement practices represent an example of decoupling between the appearance and the reality of the facts. The absence of correction (of accounting information) can be understood as an example of decoupling in the accounts presented by the managers. The adoption of this practice can be justified because it reflects a lower performance in the eyes of stakeholders.

Accounts are often a central component of the formal structure and represent an economic and organizational measure. Accounts, like languages, are used to convey an image of the world. That is, accounting is intermixed with power structures and with the interests of social actors and can be used for the defense and justification of the actions and interests of specific groups, both within the organizations and within their organizational field. An accounting practice can be viewed as an instrument with which to monitor the actions of social actors. For example, the treasury uses accounting practices to monitor its economic and financial interests, as well as to monitor social actors. The meaning of accounting information depends on how it is used. Carruthers (1995) stated that the attention given to information should be moved from "syntax" and "semantics" to a "pragmatic" view because the role of accounting is to act as a mirror, reflecting economic 
and organizational reality. In this context, accounting is used to quantify the qualities of the social and organizational world, making them predictable and calculable (Miller, 1992).

Accounting is an instrument with which to legitimize organizational actions and strategies, and Kury (2007, p. 377) stated that in the field of "US financial markets," the standards that demonstrate legitimacy derive from accounts. The legitimacy of accounts is based on the assumptions of the three institutional pillars (regulative, normative and cognitive-cultural).

The regulative pillar represents those who establish and codify the rules of accounting through legal and coercive power, and it represents the organizations or groups where they are codified; that is, a group of actors determines which financial figures represent signals in the institutional field, the accounting standards prepared by the Financial Accounting Standards Board (FASB) / Comitê de Pronunciamentos Contábeis (CPC), the mandates of the Securities and Exchange Commission (SEC) / Comissão de Valores Mobiliários (CVM) and the rules of disclosure. It is within this pillar that the standards for accounting, reporting and disclosure requirements are formulated, the tax rules are codified and the supervisory functions are established. This process of accounting regulation results in the coercive isomorphism of annual financial reports and tax returns, which offers a comparative and standardized basis that produces a perpetuation of accounts, representing a measure of legitimacy (Kury, 2007).

The normative Pillar represents the process in which the accounts are certified and validated. In this pillar, the actors interpret rules, validate compliance and evaluate performance. Kury (2007) noted that there are two forms of legitimacy within the normative pillar: the accuracy of the accounts and the performance quality. Richardson (1987) added that the accounting profession serves as a legitimizing institution and validates the accuracy of accounts and financial reports through the audit. Therefore, the normative role of accounting is to support the regulative rules of accounts because the market analysts and the fund managers interpret the reports, providing legitimacy to the company's performance, and issue recommendations to buy and sell shares, thereby maximizing shareholder value. In addition, actions related to professional education and certifications are undertaken. This process results in the normative isomorphism of accounts, where the accounts are aligned with the professional expectations of the normative institutional actors (Kury, 2007).

The cognitive-cultural pillar represents the context in which the actors operationalize accounts and where accounting legitimacy is based on compliance with social norms. The social actors seek to make comparisons between groups within the same institutional field, using standards from competing industries, or benchmarks, and historical performance and market indexes, which are elements that legitimize the accounts. Through mi- metic isomorphism, the publicly traded companies show similar earnings trends, dividend policies and quarterly earnings generation (Kury, 2007).

Accounts represent logical mechanisms for the display of legitimacy, in which the regulatory actors establish accounting standards, the normative agents validate the accounts and assess the organizational performance and the cultural-cognitive agents use the accounts to construct and operationalize the social norms. In the cognitive-cultural pillar, therefore, the common logic of the institutional actors is based on "maximizing shareholder value," which represents the basis for defining strategies. Based on this logic, the institutional actors in the "financial and capital market" build a system of legitimacy for their actions and strategies (Meyer \& Rowan, 1991; Suchman, 1995) because shareholder value is obtained through an examination of accounts and, therefore, by company profit or market yield. Thus, the financial and accounting figures represent a logical measure for determining legitimacy.

However, Kury (2007) stated that when the accounts do not reach a level of performance that meets the standards of legitimacy, the social actors can create a distance between the structure and the activity (Meyer \& Rowan, 1991), which leads to a decoupling of the accounts and the results (performance) through profit management. Therefore, Kury (2007, p. 378) stated that "the decoupling of profits occurs to compensate for inconsistencies, complexities and uncertainties in the business world." Accounting summarizes and reduces a highly complex social and organizational mass into a single item, namely the net profit. Accounts are used to record and monitor events, operations and the individual behavior of actors, as well as to evaluate and control organizational processes and results. Accounts facilitate the creation and management of information and are included among a wider set of information practices. They are used to supplement or even replace an individual or an organizational memory (Yates, 1989). By providing quantification, documentation and evaluation as a premise for decisions, accounts reinforce the limited cognitive capacity of decision-makers. Carruthers (1995) concluded in his study that what or who is responsible for a decision is often more important than the actual result of the decision itself. In fact, when the relationship between the organizational means and the ends is uncertain, or when the results are ambiguous, the legitimacy of the decision-maker is stronger than the result itself.

Johansson and Siverbo (2009) highlighted the idea that decoupling is used to describe the discrepancy between the rules and the practice; however, they called attention to the fact that decoupling occurs intentionally, that it is either an almost inevitable consequence between large organizations and their stakeholders due to the incompatibility of certain standards or a consequence of the level of internal conflict and a lack of confidence in accountants. 


\subsection{Accounting routines and practices}

Inflation is not a phenomenon that is exclusive to Brazil; countries such as the UK, the US, Japan and Germany have experienced periods of high inflation that resulted in a process where the regulatory bodies set accounting standards to guide recognition of the effects of price changes (inflation) on financial accounting. Contrary to popular belief, the notion of indexation as an option to mitigate the consequences of price fluctuations is quite old. For example, in Brazil, inflation adjustment (indexation) was institutionalized ${ }^{1}$ approximately 30 years ago, with the basic purpose of mitigating the adverse effects of inflation, which was spreading throughout the country. Throughout history and throughout the world, during times of high inflation, various actions have been taken to remedy the effects of inflation on businesses and individuals. By relating the effects of inflation to business routines, Famá (1980) noted that inflation is

a phenomenon of monetary loss, the economic effects of which should be reflected in financial statements. It erodes the purchasing power of money, distorts calculated gains, essentially flattening them, renders cash flow unmanageable, decapitalizes companies, leading some to situations of illiquidity as they rely on legal favors to avoid bankruptcy, changes the habits of the market causing some businesses to disappear, distorts the magnitude of relative values and creates optical illusions regarding values of profits and net worth. (Famá, 1980, p. 67)

In times of inflation, money loses its characteristic homogeneity, a required characteristic for adding or aggregating the transactions that occur during the operating cycle. Therefore, the existence of inflation makes the perception of the actual value relative to the input difficult (Gonzalez, 1999). In this sense, Famá (1980) added that inflation affects firms in different ways, depending on how the input costs behave in the market. The variables that are used to measure inflation can vary depending on the type of user, regardless of whether it is the government, a businessman, a homemaker or a student.

González (1999) specified that the factors that stimulate the existence of inflation involve dynamic growth, which leads to a tendency for prices and costs to increase, which in turn can favor some sectors. This process of inflation is determined by two factors: (1) increases in demand-inflation occur because the supply is not capable of meeting the increased demand, thus causing price increases; and (2) increased costinflation is caused by an increase in costs, having to import equipment needed to develop production processes, the rigidity of the economic structure of the corporate financial policies or wage increases caused by union pressures.
In addition to these factors, inflation affects the economy in three ways. (1) Inflation affects the redistribution of income or wealth because income rises more slowly than the growth rate of prices, which benefits those who have real assets. (2) Inflation affects the balance of payments in countries that show an increase in prices above the external average, and exports become less competitive and tend to decrease; under these conditions, imports are more attractive due to their lower relative price and can increase, thereby producing a deteriorating trade balance and balance of payments. (3) Inflation creates psychological effects, i.e., it establishes a climate of insecurity where claims of nominal incomes increase and demand shrinks. The climate of insecurity paralyzes existing projects (González, 1999).

In relating the effects of inflation to accounting information, Matias (1972, p. 90) reported that "inflation, however, can distort the values of assets, the available and feasible, reducing the balance to an accounting figure without truth and without sense. It is this phenomenon that gave birth to illusory profits." The author concluded that without the practice of indexation in an inflationary period, there is no possibility of producing distortion-free balance sheets or evaluating a company's actual profits.

Installing and accelerating an inflationary regime causes the fixed asset values to become a falsehood if the values are kept in historical currency as opposed to current currency. Inflation can generate fictitious results (profits), undue distributions and the formation of unjustifiable funds. This phenomenon, if left untreated, can lead to wastage and/or the erosion of the capital of an organization (Matias, 1972; Famá, 1980).

The institutional logic that supports the maintenance of "indexation" practices in organizations refers to the fact that accounting information that is not adjusted for the effects of inflation loses its usefulness for economic decision-making. Thus, this practice becomes a permanent routine in organizations that need to disclose their financial information to various users. Friedland and Alford (1991) noted that accepted behaviors in the organizational field are legitimized by the institutional logic shared by the actors.

Accounting restatement practices become routine in organizations when they enable the actors to meet the prevailing institutional logic in relation to the quality and the usefulness of the accounting information produced. In this context, Becker (2004), who researched the effects of routines on the behavior of organizations, noted the following: (1) routines are a type of truce between the various interests in organizations, and they facilitate the coordination of activities; (2) routines demonstrate some degree of stability in organizational behavior; (3) routines can be the source of behavioral inconsistency in organizations; and (4) routines are

'According to Zucker (1991, p. 83), institutionalization refers to a "process by which each individual transmits what is defined socially as real and at the same time at any point in the process, the meaning of an act can be defined to a greater or lesser extent as taken for granted in this social reality." 
conducive to knowledge and not just tacit knowledge.

Routines are derived from the ability of an organization to streamline a series of conditions, interrelationships and a sequence of behaviors between various individuals within the organization. However, Hodgson and Knudsen (2004, p. 290) argued that routines are not behaviors; they represent stored behavioral capabilities or capacities.

Routines involve organizational structures and individual habits that, when activated, lead to sequential behaviors. Hodgson and Knudsen (2004, p. 290) illustrated that in a company where all employees and managers work only during the week, there are a number of organizational routines. These routines do not disappear as a result of the company being inactive over the weekend; instead, they emerge again in response to appropriate stimuli.

Johansson and Siverbo (2009) did not define a routine as the way in which activities are actually performed, but rather as a disposition to act or behave in a certain way. According to them, routines are stored dispositions toward actions that are triggered by environmental stimuli because they occur in groups, even when they are performed every day. They emphasized that "the way things are actually performed" does not require actual conceptualization but can be viewed as a behavior or a practice, even when directed by a routine.

Routines can be viewed as having different types or dimensions. According to Scapens (2006), routines can represent a simple assumed behavior where the actors simply subordinate themselves to the power of certain people in the organization. Along these lines, Scott (2001) described three dimensions that could be covered by routines: regulative, normative and culturalcognitive.

The use of accounting restatement practices can represent an organizational routine in which the routine's repetition by accountants and managers represents an alternative solution to the informational demands of the actors in the organizational field (capital market). Collier (2005) noted that the creation and establishment of control systems include an accountability function, thus pushing the boundaries of traditional accounting and exerting social control over employees.

However, the abandonment of this accounting practice can be associated with sources of contradictions in the institutionalized routines and the prevailing institutional logic. Seo and Creed (2002) identified four sources of contradictions in routines: (1) inefficiency resulting from the pursuit of legitimacy; (2) the inability to adapt as a result of dependency patterns and blocking; (3) the incompatibility of routines; and (4) conflicts of interest (as a consequence of clashes between isomorphic pressure and other interests). Hodgson and Knudsen (2004) noted that a routine can disappear if not maintained and repeated. In addition, other routines can emerge and become stronger through interaction with the environment, resulting in the development of a new repertoire of routines that alters the nature of the group of institutionalized routines.

\subsection{The relevance of inflation-adjusted financial information}

The measurement of the effects of inflation on transactions undertaken by companies, as well as the impact of inflation on their results, has been the subject of numerous studies in the US market. It should be emphasized that international research on the relevance of "inflation-adjusted financial information" has considered the perceptions of many information users. The methodological strategies used have been varied, such as the use of the survey questionnaire, interviews (with accountants, financial directors and union directors) and econometric analysis using financial data published by companies.

Table 1 presents a summary of the research on inflation-adjusted financial information, from which it is clear that there is no consensus regarding the usefulness of this information.

Table 1 A summary of research on inflation-adjusted financial information

\begin{tabular}{|c|c|c|}
\hline Authors / year & Research & Findings \\
\hline $\begin{array}{l}\text { Dyckman } \\
(1969)\end{array}$ & $\begin{array}{l}\text { Used nominal statements adjusted by price level; } \\
\text { financial analysts were encouraged to suggest the } \\
\text { appropriate prices for the initial public offerings } \\
\text { of shares of two hypothetical firms. }\end{array}$ & $\begin{array}{l}\text { The results showed that constant currency information weighs less in the decisions } \\
\text { of analysts. }\end{array}$ \\
\hline $\begin{array}{l}\text { Mautz Jr. } \\
\text { (1990). }\end{array}$ & $\begin{array}{l}\text { Investigated the usefulness of financial statements } \\
\text { adjusted for inflation. }\end{array}$ & $\begin{array}{l}\text { Found that disclosure did not provide evidence for the usefulness of the adjusted } \\
\text { information and that the results attracted little enthusiasm among investors and } \\
\text { creditors. }\end{array}$ \\
\hline $\begin{array}{l}\text { Baran and Ofer } \\
\text { (1980) }\end{array}$ & $\begin{array}{l}\text { Researched the predictive ability of adjusted } \\
\text { financial information. }\end{array}$ & $\begin{array}{l}\text { Found evidence that a discriminant model using data in constant currency is } \\
\text { better than a model based on historical cost data in the prediction of the risk and } \\
\text { valuation of "bond ratings" securities. }\end{array}$ \\
\hline $\begin{array}{l}\text { Freishkoff } \\
(1982)\end{array}$ & $\begin{array}{l}\text { Researched the usefulness of adjusted financial } \\
\text { information. }\end{array}$ & Verified that little evidence exists that adjusted financial information is useful. \\
\hline $\begin{array}{l}\text { Beaver and Lan- } \\
\text { dman (1983) }\end{array}$ & $\begin{array}{l}\text { Analyzed the pronouncements of the Statement } \\
\text { of Financial Accounting Standards (SFAS) no. } \\
33 \text { and researched the use of adjusted financial } \\
\text { information in capital markets. }\end{array}$ & $\begin{array}{l}\text { The results of their findings offer no evidence regarding the informational capacity } \\
\text { of financial data adjusted for inflation. }\end{array}$ \\
\hline
\end{tabular}




\begin{tabular}{|c|c|c|}
\hline Authors / year & Research & Findings \\
\hline $\begin{array}{l}\text { Beaver et al. } \\
(1982)\end{array}$ & \multirow{3}{*}{$\begin{array}{l}\text { Studied the informational capacity of adjusted } \\
\text { information. }\end{array}$} & $\begin{array}{l}\text { Found no evidence that adjusted information has incremental informational capa- } \\
\text { city in profits measured. }\end{array}$ \\
\hline $\begin{array}{l}\text { Lustgarten } \\
(1982)\end{array}$ & & $\begin{array}{l}\text { Detected reactions to data related to Accounting Series Release (ASR) no. } 190 \text { but } \\
\text { were unable to determine whether the effects resulted from the ASR no. } 190 \text { or } \\
\text { alternative sources of information. }\end{array}$ \\
\hline Matolcsy (1984) & & Detected marginal information in the data adjusted for inflation. \\
\hline $\begin{array}{l}\text { Brayshaw and } \\
\text { Miro (1985) }\end{array}$ & $\begin{array}{l}\text { Analyzed the disclosure of the current cost of } \\
\text { stock prices in the UK. }\end{array}$ & Found no effect of disclosure on stock prices. \\
\hline Olsen (1985) & $\begin{array}{l}\text { Examined the effects of financial data measured } \\
\text { by the general level of prices and the current } \\
\text { costs on the stock price of electrical companies. }\end{array}$ & Did not verify the informational content in the disclosure based on SFAS no. 33 . \\
\hline $\begin{array}{l}\text { Bublitz et al. } \\
(1985)\end{array}$ & $\begin{array}{l}\text { Studied disclosure based on SFAS no. } 33 \text { and ASR } \\
\text { no. } 190 .\end{array}$ & $\begin{array}{l}\text { Concluded that disclosure drawn from the SFAS no. } 33 \text { is associated with the } \\
\text { information used by the market to set share prices and claimed that there is little } \\
\text { indication that inflation-adjusted financial statements are useful in investment } \\
\text { decisions. }\end{array}$ \\
\hline
\end{tabular}

Table 2 presents a summary of the research related information for unions. It is noted that the results are to studies of the relevance of inflation-adjusted financial again contradictory and non-convergent.

Table 2 A summary of research on the importance of inflation-adjusted financial information to unions

\begin{tabular}{|c|c|c|}
\hline Authors / year & Research & Findings \\
\hline Pillsbury (1958) & $\begin{array}{l}\text { Checked if unions use published financial statements in the } \\
\text { same way as investors and creditors with the aim of evaluating } \\
\text { past performance and making decisions about the future. }\end{array}$ & $\begin{array}{l}\text { Observed that a lack of uniformity and comparability resul- } \\
\text { ting from the availability of alternative accounting procedures } \\
\text { can be an inconvenience to union leaders. }\end{array}$ \\
\hline Palmer (1977) & $\begin{array}{l}\text { Analyzed the timing and selectivity of informational disclosure } \\
\text { supporting bargaining positions. }\end{array}$ & $\begin{array}{l}\text { Found that the increased availability of financial information } \\
\text { allowed both sides to bargain more professionally and arrive } \\
\text { at the establishment of an optimum point in the negotiation. }\end{array}$ \\
\hline $\begin{array}{l}\text { Owen and Lloyd } \\
\text { (1985) }\end{array}$ & $\begin{array}{l}\text { Analyzed the use of information in collective bargaining betwe- } \\
\text { en companies and unions to determine wages. }\end{array}$ & Found that financial information is relevant. \\
\hline Mautz Jr. (1990) & $\begin{array}{l}\text { Examined the impact of additional disclosure (inflation- } \\
\text { adjusted financial statements) for unions as a way to evaluate a } \\
\text { company's ability to pay. }\end{array}$ & $\begin{array}{l}\text { Found that financial information is not useful to unions be- } \\
\text { cause it can be confusing to these users. }\end{array}$ \\
\hline $\begin{array}{l}\text { Foley and Maunders } \\
\text { (1997) }\end{array}$ & $\begin{array}{l}\text { Conducted a review of the empirical research on the causal } \\
\text { relationship between financial information and wage rates. }\end{array}$ & Found evidence that unions can influence wage inflation. \\
\hline
\end{tabular}

Table 3 presents summaries of the results of the stu- duced under ASR no. 190 and SFAS no. 33. dies on the interests of various users in disclosure pro-

Table 3 A summary of research on users' interest in disclosure under ASR 190 and SFAS 33

\begin{tabular}{l|l|l}
\hline Authors / year & Research & Findings \\
\hline Seed (1978) & $\begin{array}{l}\text { Interviewed developers and users of financial } \\
\text { information. }\end{array}$ & $\begin{array}{l}\text { Found that respondents are unanimous in believing that the ASR no. 190 and SFAS } \\
\text { no. 33 data are misleading or useless. Reported that the interests of the developers } \\
\text { and the users of information were related to obtaining tax benefits and not to the } \\
\text { evaluation of corporate financial performance. }\end{array}$ \\
\hline $\begin{array}{l}\text { Arthur Young } \\
(1982)\end{array}$ & $\begin{array}{l}\text { Conducted a survey among officials in the } \\
\text { financial area and "senior financial officers" }\end{array}$ & $\begin{array}{l}\text { Respondents questioned the effectiveness of the costs of making supplementary } \\
\text { information mandatory. }\end{array}$ \\
\hline $\begin{array}{l}\text { Cornick (1982) } \\
\text { Conducted a survey among the directors of }\end{array}$ & $\begin{array}{l}\text { Found that they had limited familiarity with the inflation accounting techniques but } \\
\text { adjusted for the effects of inflation in financial statements and accounting. Conclu- } \\
\text { ded that bankers are interested in inflation-adjusted financial information but believe } \\
\text { that SFAS no. 33 disclosure is of little use. }\end{array}$ \\
\hline $\begin{array}{l}\text { McCaslin and } \\
\text { Stanga (1982) }\end{array}$ & $\begin{array}{l}\text { Conducted a survey among the CFOs of Fortu- } \\
\text { ne 500 companies. }\end{array}$ & $\begin{array}{l}\text { Indicated that CFOs view historical cost information as more relevant and more } \\
\text { reliable than information in constant currency or current cost. }\end{array}$ \\
\hline $\begin{array}{l}\text { Flesher and } \\
\text { Soroosh (1983) }\end{array}$ & Interviewed financial analysts and controllers. & Reported that respondents consider that SFAS no. 33 disclosure is of little use. \\
\hline
\end{tabular}


From the discussion of the assumptions regarding the institutional approach and the results on the use of indexation practices in other countries, we opted to use the theoretical approach proposed by Oliver (1991, 1992), which is used to analyze how institutional pressures encourage the deinstitutionalization process of devices, habits, routines and institutions, considering the internal and external pressures on organizations. In this context, Scapens (2006) stated that the process of change in organizations is complex because it depends on existing forms of thought (institutions), the circuits of power and the level of confidence in the accountants, which can have an impact on how the actors within the organization respond to external institutional and economic pressures.

\subsubsection{The deinstitutionalization process.}

The process of deinstitutionalization, unlike the change process, has received little attention from scholars (Scott, 2001; Machado-da-Silva et al., 2005). Deinstitutionalization refers to the process through which institutions weaken and disappear. In this process, the importance of beliefs, behaviors, schemes and resources is emphasized. Previous studies reinforced the procedural and dynamic view of institutionalization and deinstitutionalization, which constitute an environment in which multiple organizations revolve around a common point, forming an organizational field (Hoffman, 1999). There are many interests involved, whi- ch limits the character of the organizational field, but it also stimulates the changes that are characteristic of institutions.

The process of deinstitutionalization is driven by the perception that a particular organizational practice no longer meets the current needs, thereby losing organizational desire or ability to maintain or continually recreate the institutionalized organizational activity (Oliver, 1992). Four reasons are given to justify the importance of research on deinstitutionalization and its specific causes: (1) neglected organizational changes can be explained from an institutional perspective as challenges to the institutional status quo, the abandonment of habits or customs and the deterioration of the organizational consensus regarding a practice or activity; (2) the stability and longevity of values and institutionalized practices can be questioned, considering that they may be subject to challenges, re-evaluations or rejections; (3) institutional pressures to conform can fail to achieve their expected effects; and (4) noninstitutionalized factors can shape the organizational responses to institutional pressures.

Environmental pressures are composed of technical and institutional aspects, which continually influence the process of institutionalizing and deinstitutionalizing social practices. Oliver (1992) divided environmental pressures into political, social and instrumental pressures, as described in Table 4.

Table 4

The antecedents of deinstitutionalization

\begin{tabular}{l|l|l|l}
\hline Level of Analysis & Political Pressures & Instrumental Pressures & Social Pressures \\
\hline \multirow{2}{*}{ Organizational } & Increase in performance crises & Change in economic utility & Increased social fragmentation \\
\cline { 2 - 3 } & Conflicting internal interests & Increased technical specifications & Break in historical continuity \\
\cline { 2 - 4 } & Increased pressures for innovation & Increased competition for resources & $\begin{array}{l}\text { Change in institutionalized values } \\
\text { or rules }\end{array}$ \\
\hline \multirow{2}{*}{ Environmental } & Change in external dependencies & Emerging data or events & Increased structural disaggregation \\
\hline
\end{tabular}

Source: Oliver (1992, p. 567).

Political, instrumental and social pressures, like institutional tools, are intended to explain the triggers for the deinstitutionalization process and the pressures toward inertia and entropy, the former making the process more difficult and the latter accelerating it (Oliver, 1992).

\subsubsection{The relationship between the process of deinstitutionalization and accounting restatement practices}

This analysis model was structured from the assumptions of deinstitutionalization (Oliver, 1992) and aims to explain the relevance of the use of accounting restatement practices, both at the organizational level and in the environment (organizational field). Oliver (1992) noted that deinstitutionalization can be motivated by political pressures, which can be driven by the increase in performance crises between managers, the existence of conflicting internal interests and/or an increase in the pressure for innovation on the part of the social actors. Therefore, the first hypothesis H1-org is proposed: There is a negative relationship between the use of accounting restatement practices and organizational and political pressures.

Given that the publication of adjusted information can influence the managers' remuneration and that of their business units or areas of responsibility (Puxty, 
1997; Scott, 2001; Martinez, 2001; Fields, Lys, \& Vincent, 2001), this variable can aid in the understanding of the process of deinstitutionalization. According to Pong and Whittington (1996), this practice does not represent informational innovation for the capital market, and its use is associated with lower rates of inflation in the economy. However, Owen and Lloyd (1985) analyzed the use of information in negotiations (collective bargaining) between companies and unions to determine wages, and their results show that financial information is relevant. Mautz Jr. (1990), however, found that inflation-adjusted financial information has no informational content for unions (employees) in the process of bargaining for wage increases and other benefits.

Oliver (1992) noted that at the environmental level, any changes in external dependencies can cause interference in the internal configuration of an organization, leading to hypothesis $\mathrm{H} 1$-env: There is a positive relationship between the use of accounting restatement practices in the organizational field and changes to external configurations.

Thus, we sought to evaluate the following variables from the environmental perspective: the lower inflation rates of the Brazilian economy; the changing laws regarding the publication of adjusted financial information; the non-requirement by financial markets; the lack of tax incentives (Seed, 1978); and the non-requirement from the matrix, customers and suppliers (Rodrik and Subramanian, 2003; Venard \& Hanafi, 2007). Other pressures that can lead to the process of deinstitutionalization include functional and instrumental pressures, which are driven by the changing levels of usefulness in a practice that was previously institutionalized. Usefulness can change due to increasing technical specifications, which can cause an imbalance in the technological processes adopted by organizations, as well as to increased competition for resources between organizations. Based on this reasoning, Oliver (1992) proposed the following hypothesis, $\mathrm{H} 2$-org: There is a positive relationship between the use of accounting restatement practices and functional changes.

To evaluate this hypothesis, we analyzed the following scenarios: the costs of maintaining the practice, outweighing the benefits of information generated (Arthur Young, 1982; Watts \& Zimmerman, 1980); the emergence of new accounting technologies influencing the process of deinstitutionalization (Ponte, Oliveira, Moura \& Carmo, 2007); the use of this information in restricting internal resources; and whether this type of information is relevant in the decision-making of investors and shareholders (Heintz, 1973; Mcintyre, 1973; Martinez, 2001).

Oliver (1992) explained that at the environmental level, the functional pressures associated with the process of deinstitutionalization can be motivated by emerging data or events attributed to the organizational field (Pong \& Whittington, 1996). Therefore, the following hypothesis $\mathrm{H} 2$-amb emerges: There is a positive relationship between the use of accounting restatement practices and emerging events in the organizational field.

Discontinuing the practice of additional disclosure can be motivated by emerging events, such as changing levels of inflation during the period (month and year), the emergence of new regulations for the economic sectors and the influence of dividend distributions (Beaver, 1998; Martinez, 2001) due to the effects of inflation on the results (Suchman, 1995).

In analyzing the change process, Oliver (1992) added that social pressures can also offer a relevant explanation for this process. These pressures can be due to the increase in social fragmentation, the disruption of historical continuity or any changes in values or institutionalized rules. Therefore, the following hypothesis $\mathrm{H} 3$-org emerges: There is a negative relationship between the use of accounting restatement practices and social organizational pressures.

From the perspective of social pressures, the process of deinstitutionalizing accounting restatement practices could be motivated by a change in a company's legal format (for example, an IPO or a delisting), changes in the organizational structure, mergers, divisions or incorporations or changes in the internal managers (social actors). Thus, the process of deinstitutionalization is associated with the differentiation of groups and the presence of divergent or discordant heterogeneous beliefs or practices (Scott 2001).

Oliver (1992) noted that social pressures at the environmental level can cause an increase in structural disaggregation in the organizational field dimension. This observation leads to hypothesis H3-env: There is a negative relationship between the use of accounting restatement practices and structural disaggregation in the organizational field.

At the environmental level, we investigated whether the process of internationalizing accounting (the international harmonization of accounting practices) contributes to the deinstitutionalization of these practices (Niyama, 2005) because this process can affect companies and their stakeholders by creating a level of shortand medium-term instability in practices and values that had been institutionalized until that point (Greenwood, Suddaby \& Hinings, 2002). In general, this model seeks to evaluate the motivating factors (pressures) in the deinstitutionalization of the adjustment for the effects of inflation on accounting information (accounting restatement practices). Table 5 shows the constructs and the hypotheses of the deinstitutionalization model used in this study. 
The deinstitutionalization model constructs and hypotheses

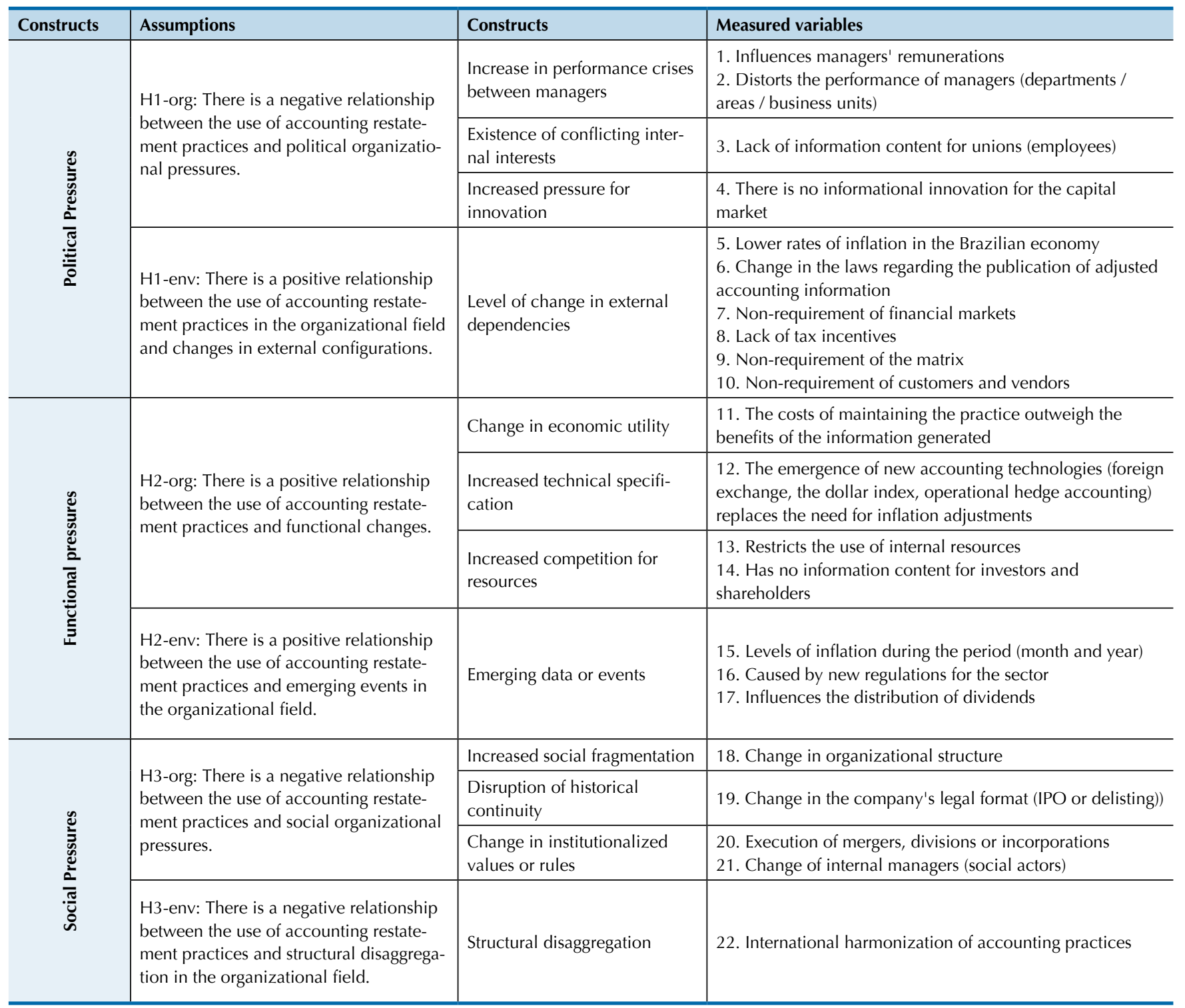

In the following sections, different statistical analyses were performed to verify the conceptual compliance with the theoretical model proposed in this analysis of the process of deinstitutionalizing accounting restatement practices.

\section{RESEARCH METHODOLOGY}

The method used in this research to analyze the proposed objectives combines quantitative and qualitative data. Vasconcelos (2007) noted that, despite having a qualitative focus, the use of nomothetic methods as criteria for the evaluation and generalization of interpretations provides a more robust analysis of the objective and subjective aspects of reality in the construction of social knowledge.

In developing the study, primary and secondary data were used and collected from various sources, such as the following: (i) questionnaires, (ii) interviews with accountants and controllers and (iii) data on economic-financial performance obtained from published reports. These methodological strategies have enabled the operationalization of indicators and the measurement of the constructs that constitute the model.
From the Exame-Best and Biggest (Exame-Melhores e Maiores) database maintained by FIPECAFI that lists the 500 largest and best companies in Brazil, 212 companies were selected that issued supplementary accounting statements containing adjusted accounting information, 61 of which were inactive. After telephone contact with the 151 active companies, it was found that 33 companies were unwilling to answer the questionnaire for various reasons, such as a company policy that did not allow managers to participate in surveys or because the company was acquired by another economic group. Thus, the sample of companies surveyed was limited to 118 companies, among which 44 valid responses were obtained (questionnaires) between the months of March and April 2009. 


\section{RESULTS AND ANALYSIS}

The analysis is divided into four stages, the first of which is a descriptive assessment of the profile of respondents and their perceptions regarding the use and importance of the practice of financial adjustment and its implications for the quality of accounting information. Regarding the profile of the survey respondents, it was found that $75.0 \%$ of the respondents were accountants and controllers and that $92 \%$ had been in the business for more than 10 years. It should be noted that this result is in accordance with the expected profile.

In the analysis of their perceptions on the qualitative characteristics of accounting information (understandability, relevance, reliability and comparability), it was found that $45.5 \%$ of the respondents indicated that they disagreed or were indifferent about the level of understandability for the inflation-adjusted financial information; however, $54.6 \%$ indicated that they agreed or completely agreed. There were no respondents who disagreed completely about understandability; $45.5 \%$ of respondents agreed with its importance, 54.5\% indicated that they believed in its reliability and $68.2 \%$ said they agreed that the inflation adjustments increase comparability. Therefore, the adjusted accounting information is not currently viewed as relevant, but once measured and evidenced, the accountants and controllers consider it to be comparable, reliable and understandable.

When investigating whether companies are performing some type of adjustment for the effects of inflation on transactions, it was found that only $2.3 \%$ of companies maintained the practice of full indexation and indexation balance, $11.4 \%$ of companies partially performed the application of sector indexes and $9.1 \%$ stated that they performed other types of adjustments for the effects of inflation.

With regard to the importance of the accounting restatement practice, it was found that $68.1 \%$ of the respondents attributed no or little importance to the use of this practice in the current economic climate for businesses. By comparison, it was observed that the personal perception of the respondents (managers) differed from the level of importance given to this practice by companies because $81.8 \%$ of the managers assigned between some and very high importance to the use of accounting restatement practices.

From the answers obtained, a score was produced ${ }^{2}$ for each variable studied, which allowed for the quantitative identification of the most representative variables in the process of deinstitutionalizing the inflation-based adjustments to financial information. Considering the variables for each construct, the ranking shown in Table 6 was obtained.

Table 6 An analysis of the variables, scores and constructs of "political, functional and social pressures"

\begin{tabular}{|c|c|c|c|c|c|c|c|c|c|c|c|c|c|}
\hline \multicolumn{4}{|c|}{ Ranking - Constructs and Variables } & \multicolumn{10}{|c|}{ Factor Analysis of Constructs } \\
\hline 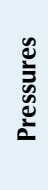 & 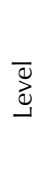 & Variables / Indicators & 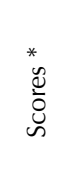 & 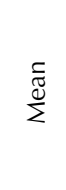 & 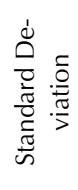 & $\bar{\varepsilon}$ & 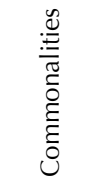 & 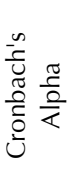 & 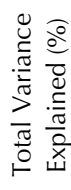 & 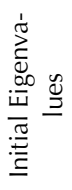 & 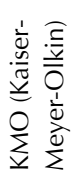 & 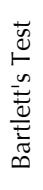 & $\ddot{n}$ \\
\hline \multirow{10}{*}{$\begin{array}{l}\frac{\mathscr{e}}{\frac{0}{0}} \\
\frac{0}{0} \\
\end{array}$} & \multirow{4}{*}{ 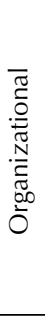 } & $\begin{array}{l}\text { Ppo1 - Influences the performance and remu- } \\
\text { neration of managers }\end{array}$ & 0.13 & 1.52 & 0.849 & 0.7768 & 0.6034 & \multirow{4}{*}{$\begin{array}{l}\stackrel{\infty}{\infty} \\
\infty \\
0\end{array}$} & \multirow{4}{*}{$\begin{array}{l}\overline{\dddot{y}} \\
\text { ஸे. }\end{array}$} & \multirow{4}{*}{$\begin{array}{l}\hat{0} \\
\text { ô } \\
i\end{array}$} & \multirow{4}{*}{$\begin{array}{l}\stackrel{\infty}{N} \\
\stackrel{0}{0}\end{array}$} & \multirow{4}{*}{$\begin{array}{l}\text { } \\
\text { ô } \\
\text { م }\end{array}$} & \multirow{4}{*}{$\stackrel{0}{8}$} \\
\hline & & $\begin{array}{l}\text { Ppo2 - Distorts the performance of depart- } \\
\text { ments, areas and business units }\end{array}$ & 0.18 & 1.73 & 0.949 & 0.9298 & 0.8645 & & & & & & \\
\hline & & $\begin{array}{l}\text { Ppo3 - Does not provide informational content } \\
\text { for unions (employees) }\end{array}$ & 0.14 & 1.55 & 1.044 & 0.8581 & 0.7363 & & & & & & \\
\hline & & $\begin{array}{l}\text { Ppo4 - Has no informational innovation for the } \\
\text { capital market }\end{array}$ & 0.27 & 2.07 & 1.108 & 0.7022 & 0.493 & & & & & & \\
\hline & \multirow{6}{*}{ 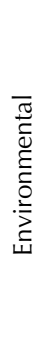 } & $\begin{array}{l}\text { Ppa1 - Lower rates of inflation in the Brazilian } \\
\text { economy }\end{array}$ & 0.56 & 3.23 & 1.476 & 0.5373 & 0.2886 & \multirow{6}{*}{ 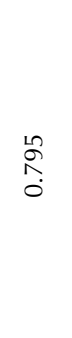 } & \multirow{6}{*}{$\begin{array}{l}\hat{1} \\
\hat{n} \\
0 \\
0 \\
\text { டे }\end{array}$} & \multirow{6}{*}{$\stackrel{+}{m}$} & \multirow{6}{*}{ 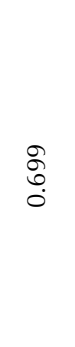 } & \multirow{6}{*}{ 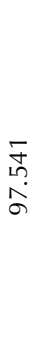 } & \multirow{6}{*}{$\begin{array}{l}8 \\
:\end{array}$} \\
\hline & & $\begin{array}{l}\text { Ppa2 - Change in the laws regarding publica- } \\
\text { tion of adjusted financial information }\end{array}$ & 0.72 & 3.86 & 1.231 & 0.7164 & 0.5133 & & & & & & \\
\hline & & Ppa3 - Not required by the financial market & 0.58 & 3.32 & 1.377 & 0.7303 & 0.5333 & & & & & & \\
\hline & & Ppa4 - Lack of tax incentives & 0.35 & 2.41 & 1.452 & 0.7512 & 0.5642 & & & & & & \\
\hline & & Ppa5 - Not required by the matrix & 0.35 & 2.41 & 1.675 & 0.6835 & 0.4671 & & & & & & \\
\hline & & Ppa6 - Not required by customers and vendors & 0.38 & 2.52 & 1.455 & 0.8174 & 0.6681 & & & & & & \\
\hline
\end{tabular}




\begin{tabular}{|c|c|c|c|c|c|c|c|c|c|c|c|c|c|}
\hline \multicolumn{4}{|c|}{ Ranking - Constructs and Variables } & \multicolumn{10}{|c|}{ Factor Analysis of Constructs } \\
\hline 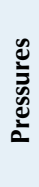 & 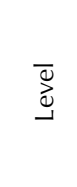 & Variables / Indicators & $\stackrel{*}{\circlearrowright}$ & $\stackrel{\frac{\pi}{\mathscr{J}}}{\stackrel{\Sigma}{\Sigma}}$ & 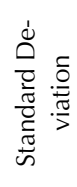 & $\overline{0}$ & 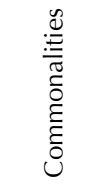 & 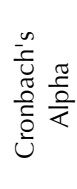 & 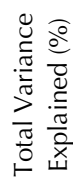 & 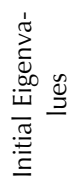 & 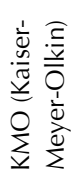 & 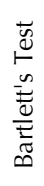 & $\frac{\infty i n}{i n}$ \\
\hline \multirow{7}{*}{ 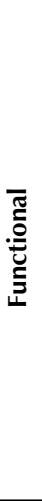 } & \multirow{4}{*}{ 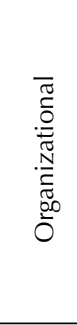 } & $\begin{array}{l}\text { Pfo1 - The cost of maintaining the practice } \\
\text { outweighs the benefits of the information } \\
\text { generated }\end{array}$ & 0.6 & 3.41 & 1.419 & 0.6905 & 0.4767 & \multirow{4}{*}{$\stackrel{0}{\stackrel{N}{N}}$} & \multirow{4}{*}{ ֻั. } & \multirow{4}{*}{$\begin{array}{l}\infty \\
\stackrel{\infty}{+} \\
i \\
i\end{array}$} & \multirow{4}{*}{$\begin{array}{l}n \\
\hat{0} \\
0\end{array}$} & \multirow{4}{*}{ 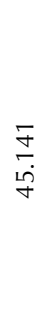 } & \multirow{4}{*}{$\S$} \\
\hline & & $\begin{array}{l}\text { Pfo2 - The emergence of new accounting } \\
\text { technologies }\end{array}$ & 0.49 & 2.98 & 1.406 & 0.8201 & 0.6725 & & & & & & \\
\hline & & Pfo3 - Restricts the use of internal resources & 0.31 & 2.25 & 1.241 & 0.8383 & 0.7027 & & & & & & \\
\hline & & $\begin{array}{l}\text { Pf04 - Has no informational content for inves- } \\
\text { tors and shareholders }\end{array}$ & 0.41 & 2.66 & 1.311 & 0.7459 & 0.5563 & & & & & & \\
\hline & \multirow{3}{*}{ 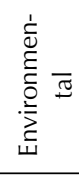 } & $\begin{array}{l}\text { Pfa1 - Levels of inflation during the period } \\
\text { (month and year) }\end{array}$ & 0.59 & 3.34 & 1.311 & 0.6839 & 0.4678 & \multirow{3}{*}{$\stackrel{\tilde{n}}{0}$} & \multirow{3}{*}{ 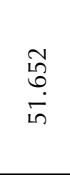 } & \multirow{3}{*}{ 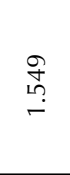 } & \multirow{3}{*}{ 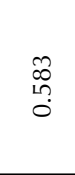 } & \multirow{3}{*}{$\stackrel{N}{\hat{N}}$} & \multirow{3}{*}{$\stackrel{\circ}{\circ}$} \\
\hline & & Pfa2 - Caused by new regulations for the sector & 0.45 & 2.82 & 1.498 & 0.7948 & 0.6318 & & & & & & \\
\hline & & Pfa3 - Influences the distribution of dividends & 0.35 & 2.41 & 1.436 & 0.6709 & 0.4501 & & & & & & \\
\hline \multirow{5}{*}{$\overline{\frac{\pi}{U}}$} & \multirow{5}{*}{ 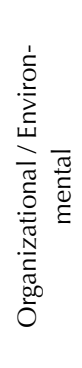 } & $\begin{array}{l}\text { Pso1 - Change in the company's legal format } \\
\text { (IPO or delisting) }\end{array}$ & 0.21 & 1.84 & 1.275 & 0.8976 & 0.8058 & \multirow{5}{*}{$\begin{array}{l}\infty \\
\infty \\
0\end{array}$} & \multirow{5}{*}{$\begin{array}{l}\hat{\curvearrowright} \\
\text { ฺु }\end{array}$} & \multirow{5}{*}{$\underset{\sim}{\stackrel{+}{n}}$} & \multirow{5}{*}{$\begin{array}{l}\stackrel{\rho}{R} \\
\dot{0}\end{array}$} & \multirow{5}{*}{$\begin{array}{l}\stackrel{\infty}{\infty} \\
\stackrel{\infty}{\mp}\end{array}$} & \multirow{5}{*}{$\stackrel{8}{\circ}$} \\
\hline & & Pso2 - Change in the organizational structure & 0.18 & 1.73 & 1.042 & 0.9242 & 0.8542 & & & & & & \\
\hline & & $\begin{array}{l}\text { Pso3 - Execution of mergers, divisions or } \\
\text { incorporations }\end{array}$ & 0.15 & 1.61 & 1.083 & 0.8476 & 0.7184 & & & & & & \\
\hline & & $\begin{array}{l}\text { Pso4 - Change of internal managers (social } \\
\text { actors) }\end{array}$ & 0.13 & 1.5 & 0.792 & 0.7819 & 0.6113 & & & & & & \\
\hline & & $\begin{array}{l}\text { Psam - International harmonization of accoun- } \\
\text { ting practices }\end{array}$ & 0.6 & 3.41 & 1.499 & 0.4745 & 0.2251 & & & & & & \\
\hline
\end{tabular}

* Represents the average for answers given on a Likert scale ( $1=$ unimportant to $5=$ very important)

Table 6 shows that the variables that constitute the political (organizational) pressures were not relevant, i.e., the internal aspects of the organization were of little relevance in explaining the process of deinstitutionalization. The political (environmental) pressures had higher scores. In particular, the variables associated with the changes to the laws on publication, the financial market's non-requirement for this type of information and the decreasing inflation rates of the Brazilian economy are worth emphasizing.

With respect to the variables that are related to the functional (organizational) pressures, the cost of maintaining the practice appears to be important. Regarding the variables that are related to the functional (environmental) pressures, it can be observed that the levels of inflation during the month and year are influential elements. Among the variables that are related to social pressures, only the variable related to the process of the international harmonization of accounting practices proved to be significant. This result is in accordance with the recommendations of the International Accounting Standards Board (IASB), which recommends the use of accounting restatement practices only when the level of inflation reaches $33 \%$ per year and $100 \%$ (cumulative) in three consecutive years.

\subsection{Factor analysis of constructs}

To analyze the constructs that most influenced the companies that discontinued the practice of financial ad- justment, the technique of factor analysis was used with the extraction of factorial scores to assess the importance/ weight of each construct. As shown in Table 6, the results of the explained variance show that the KMO and the eigenvalues in the model based on assumptions of deinstitutionalization (Oliver, 1992) are consistent with the statistical recommendations (Hair Jr., 2005).

Based on the factor analyses performed and the identification of factors (pressures) and scores, an analysis was prepared to identify the relevance and the influence of each factor (construct) in the process of deinstitutionalizing the accounting restatement practices. Regarding the interpretation of the standardized factor scores, Bido (2009) argued that if all items are measured on a Likert scale from 1 to 5 , having the factor score on the same scale as the indicators would facilitate the interpretation of results and enable the implementation of other analyses based on these scores.

Thus, the standard scores (factor analysis) were transformed to the item scale. This procedure is performing using the SmartPLS (www.smartpls.de) software to obtain non-standardized scores for the latent variables (Bido, 2009). This procedure was formalized by Fornell, Johnson, Anderson, Cha and Bryant (1996, p. 17) and detailed by Tenenhaus, Vinzi, Chatelin and Lauro (2005, p.167). Table 7 shows the calculated mean of the non-standard factor scores for each analysis model construct based on assumptions of deinstitutionalization. 
Table 7 The descriptive statistics for non-standardized factor scores

\begin{tabular}{l|c|c|c|c|c}
\hline & N & Minimum & Maximum & Mean & Standard Deviation \\
\hline Political - Organizational_N & 44 & 1.00 & 4.00 & 1.6913 & 0.80511 \\
\hline Political - Environmental_N & 44 & 1.00 & 4.88 & 2.9794 & 1.02402 \\
\hline Functional - Organizational_N & 44 & 1.00 & 4.58 & 2.7775 & 1.04065 \\
\hline Functional - Environmental_N & 44 & 1.00 & 5.00 & 2.8719 & 1.01981 \\
\hline Social - Organizational / Environmental_N & 44 & 1.00 & 4.00 & 1.8086 & 0.87441 \\
\hline Valid N (list-wise) & 44 & & & & \\
\hline
\end{tabular}

To facilitate the analysis, Figure 1 shows the means of means of the non-standard scores are not equal. the non-standard factor scores. It can be observed that the

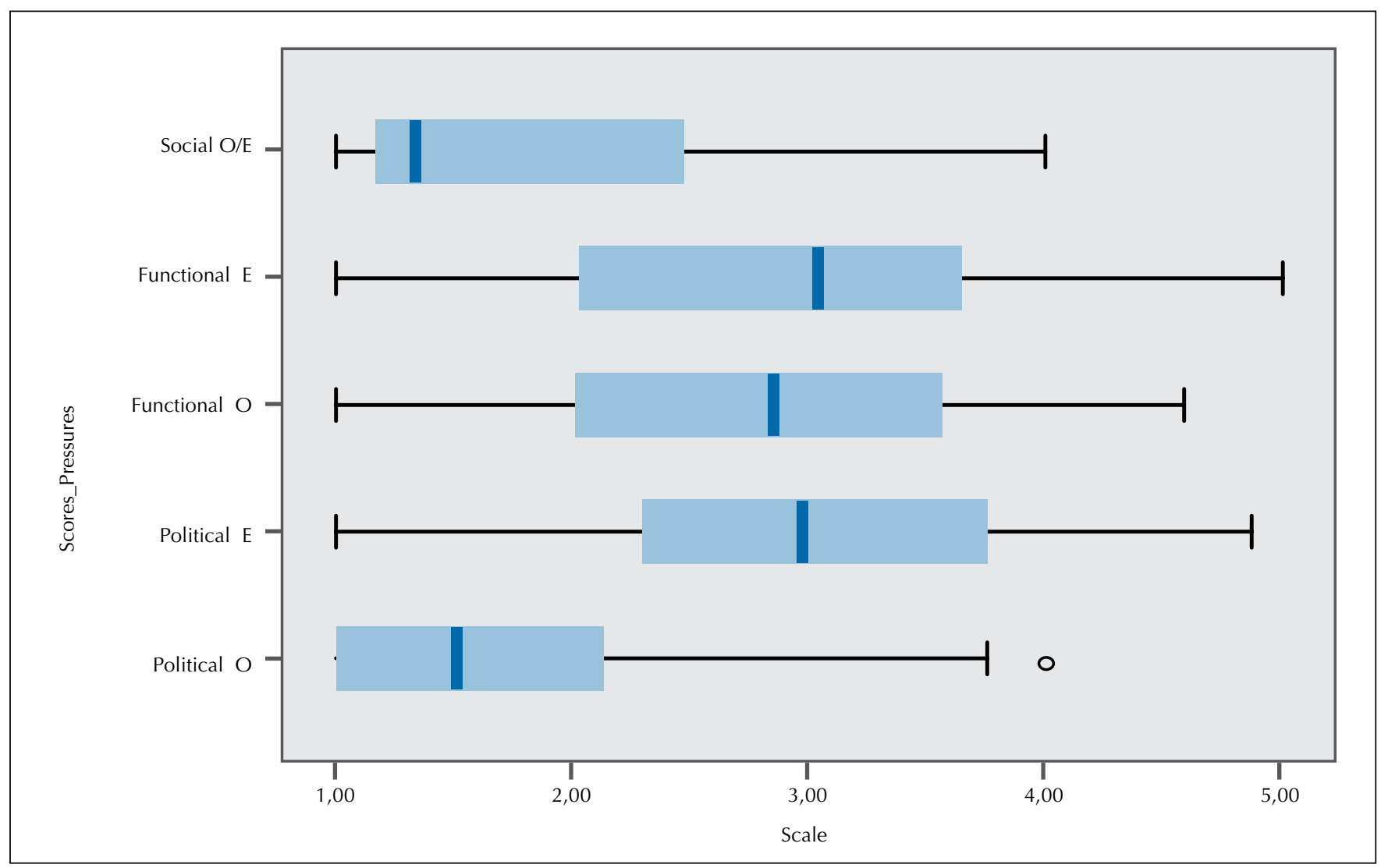

Figure 1 The means of the non-standard scores (deinstitutionalization)

\subsubsection{An evaluation of the relevance of the theoretical constructs}

To assess whether there were significant differences between the constructs (deinstitutionalization), the Kruskal-Wallis nonparametric statistical technique was used, which can be applied to ranked data or used to study nominal variables. The technique is also applicable in the analysis of small samples because it does not depend on the population or sampling parameters. The test is used to determine whether $\mathrm{K}$ independent samples $(\mathrm{K}>2)$ are from populations with equal medians (Maroco, 2003). This test is a non-parametric alternative to the one-way ANOVA that is used to test two or more samples from the same or different populations with the same distribution ${ }^{3}$.

\subsubsection{Deinstitutionalization - the Kruskal-Wallis test}

Table 8 shows the mean ranks of scores (constructs). It is evident that the political (organizational) and the social pressure constructs were not as significant in explaining the phenomenon of deinstitutionalization.

The results confirm the hypothesis that the political (environmental) and functional (organizational and environmental) pressure constructs are more significant in explaining the process of deinstitutionalizing the accounting restatement practices. As shown in Table 9, the results obtained from the Kruskal-Wallis test indicate that the construct medians (deinstitutionalization: political, functional and social pressures) are significantly different because the $p$-value $=0.000<\alpha=0.05$, indicating the rejection of $H_{0}$ in favor of $H_{1}$. Therefore, it is possible to 
identify the constructs that are the most relevant in explaining the phenomenon.

A one-way ANOVA was used to compare the means of more than two populations. This test assumes that the distribution of the variable is normal and that the popu- lation variances are homogeneous (Maroco, 2003). Specifically, the ANOVA compares the relative proportion of variance within the samples with the variance between the samples or groups.
Table 8 Ranking

\begin{tabular}{c|l|c|c}
\hline \multicolumn{2}{|c|}{ Group-II } & N & Mean rank \\
\hline Pressures & Political Org. & 44 & 67.31 \\
\hline & Political Env. & 44 & 140.73 \\
\hline & Functional Org. & 44 & 131.59 \\
\hline & Functional Env. & 44 & 136.35 \\
\hline & Social Org/Env. & 44 & 76.52 \\
\hline & Total & 220 & \\
\hline
\end{tabular}

Table $9 \quad$ Test statistics

\begin{tabular}{c|c}
\hline Deinstitutionalization & \\
\hline Chi-Square & 55.145 \\
\hline DF & 4 \\
\hline Asymp. Sig. & 0 \\
\hline
\end{tabular}

a. Kruskal-Wallis test b. Grouping variable: Group I

Table 10 One-sample Kolmogorov-Smirnov test

\begin{tabular}{|c|c|c|c|c|c|c|}
\hline & & Ppo_N & Ppa_N & Pfo_N & Pfa_N & Psoa_N \\
\hline \multicolumn{2}{|c|}{$\mathrm{N}$} & 44 & 44 & 44 & 44 & 44 \\
\hline \multirow[t]{2}{*}{ Normal Parameters $(\mathrm{a}, \mathrm{b})$} & Mean & 1.6913 & 2.9794 & 2.7775 & 2.8719 & 1.8086 \\
\hline & Std. Deviation & 0.80511 & 1.02402 & 1.04065 & 1.01981 & 0.87441 \\
\hline \multirow[t]{2}{*}{ Most Extreme Differences } & Absolute & 0.195 & 0.076 & 0.08 & 0.195 & 0.248 \\
\hline & Positive & 0.191 & 0.076 & 0.07 & 0.089 & 0.248 \\
\hline Kolmogorov-Smirnov Z & & 1.295 & 0.504 & 0.532 & 0.813 & 1.643 \\
\hline Asymp. Sig. (Two-tailed) & & 0.07 & 0.961 & 0.94 & 0.524 & 0.009 \\
\hline
\end{tabular}

a. Test distribution is normal ; b. calculated from the data.

Table 11 Test of the homogeneity of variances

\begin{tabular}{c|c|c|c}
\hline Levene Statistic & df1 & Df2 & Sig. \\
\hline 1.13 & 4 & 215 & 0.343 \\
\hline
\end{tabular}

Table 12 The deinstitutionalization ANOVA test

\begin{tabular}{c|c|c|c|c|c}
\hline & Sum of Squares & Df & Mean Square & F & Sig. \\
\hline Between Groups & 67.255 & 4 & 16.814 & 18.407 & 0 \\
\hline Within Groups & 196.393 & 215 & 0.913 & & \\
\hline Total & 263.648 & 219 & & & \\
\hline
\end{tabular}

Table 10 shows the results of the Kolmogorov-Smirnov test, which was used to evaluate the normality of the nonstandardized scores. It is noteworthy that the normal distribution was not obtained for the variables of the deinstitutionalization model, but a normal distribution was obtained for the non-standardized scores, as shown in Table 10.

The Levene test is considered to be a more robust test for comparing population $\mathrm{k}$ means from representative $\mathrm{k}$ samples and for verifying whether the population variances are homogeneous. As shown in Table 11, according to the Leve- ne test, it is recommended that the hypothesis that the score variances (constructs) are homogeneous be accepted. Table 12 shows the results obtained from the one-way ANOVA with a $5 \%$ probability of error, and it can be concluded that the constructs are significantly different (pressures: political, social and functional) ( $p$-value $=0.000<\alpha=0.05$, indicating the rejection of $H_{0}$ in favor of $\left.H_{1}\right)$. The ANOVA test allows us to conclude that there are at least two different means; in addition, from the data presented in Table 13, it is possible to identify which means are different. 
Table 13

Different means

\begin{tabular}{l|l|l|l|l|l}
\hline (I) Group-II & (J) Group-II & Different Means (I-J) & Standard Error & Sig. & Análises \\
\hline Political - org. & Political - env. & $-1.26864\left(^{*}\right)$ & 0.20377 & 0.000 & Are different \\
\hline & Functional - org. & $-1.08591\left(^{*}\right)$ & 0.20377 & 0.000 & Are different \\
\hline & Functional - env. & $-1.18068\left(^{*}\right)$ & 0.20377 & 0.000 & Are different \\
\hline & Social - org./env. & -0.11705 & 0.20377 & 0.979 & Are not different \\
\hline & Political - org. & $1.26864\left(^{*}\right)$ & 0.20377 & 0.000 & Are different \\
\hline & Functional - org. & 0.18273 & 0.20377 & 0.898 & Are not different \\
\hline & Functional - env. & 0.08795 & 0.20377 & 0.993 & Are not different \\
\hline & Social - org./env. & $1.15159\left(^{*}\right)$ & 0.20377 & 0.000 & Are different \\
\hline & Political - org. & $1.08591\left(^{*}\right)$ & 0.20377 & 0.000 & Are different \\
\hline & Political - env. & -0.18273 & 0.20377 & 0.898 & Are not different \\
\hline & Functional - env. & -0.09477 & 0.20377 & 0.990 & Are not different \\
\hline & Social - org./env. & $0.96886\left(^{*}\right)$ & 0.20377 & 0.000 & Are different \\
\hline & Pres. Polít - org & $1.18068\left(^{*}\right)$ & 0.20377 & 0.000 & Are different \\
\hline & Political - env. & -0.08795 & 0.20377 & 0.993 & Are not different \\
\hline & Functional - org. & 0.09477 & 0.20377 & 0.990 & Are not different \\
\hline & Social - org./env. & $1.06364\left(^{*}\right)$ & 0.20377 & 0.000 & Are different \\
\hline & Political - org. & 0.11705 & 0.20377 & 0.979 & Are not different \\
\hline & Political - env. & $-1.15159\left(^{*}\right)$ & 0.20377 & 0.000 & Are different \\
\hline & Functional - org. & $-0.96886\left(^{*}\right)$ & 0.20377 & 0.000 & Are different \\
\hline & Functional - env. & $-1.06364\left(^{*}\right)$ & 0.20377 & 0.000 & Are different \\
\hline
\end{tabular}

Multiple comparisons (Tukey HSD): the mean difference is significant at the $5 \%$ level.

Table 13 shows the following: in the first comparison, the mean score (construct) for political pressures (organizational) is different from the mean for functional pressures (organizational and environmental); in the second comparison, the mean for political pressures (organizational) is different from the mean for political (environmental) and social (organizational / environmental) pressures; in the third comparison, the mean for functional pressures (organizational) is different from the mean for social pressures (organizational / environmental); in the fourth comparison, the mean for functional pressure (environmental) differs from the mean for social pressures (organizational / environmental); and in the fifth comparison, it appears that the mean for social pressures (organizational / environmental) was not significantly different from the mean for political pressures (organizational).

\section{CONCLUSIONS}

The purpose of this research was to identify the relevance of the institutional pressures inherent in the process of abandoning the accounting restatement practices in Brazilian companies. From the approach proposed by Oliver (1992), which included 22 variables comprising 12 constructs and 6 qualitative hypotheses, the motivating factors (pressures) for the process of deinstitutionalizing the accounting restatement practices were sought. We examined whether there is a correlation (negative/positive) between the theoretical constructs on the political, functional and social pressures that constitute the process of deinstitutionalizing the use of accounting restatement practices in Brazilian companies. The qualitative hypotheses that comprised the analysis were as follows.

- H1-org (-) Organizational political pressures - The results showed that none of the variables (managers' pay and performance, conflicting internal interests and informational innovation of the capital markets) were influential in the process of deinstitutionalization based on the means obtained (1.52, 1.73, 1.55 and 2.07, respectively; Table 6). These results were confirmed in the interviews.

- H1-env: (+) Changes in external settings - These changes were significant, motivated by the Brazilian program for economic stabilization and the lack of demand for adjusted information by the financial lending market. Because of the means obtained (3.23, 3.86 and 3.32 ), it is important to highlight three of the six variables that were measured in this construct: (i) changes in the laws on the publication of adjusted financial information; (ii) reduction in the inflation rates in the Brazilian economy; and (iii) the requirements of the financial market.

- H2-org: (+) Functional changes (economic utility, increased technical specifications and increased competition for resources) - The results show that the cost versus the benefit of the information and the emergence of new technologies were the preponderant variables associated with not maintaining the accounting restatement practices based on the means obtained (3.41 and 2.98). 
The competition for resources was not an influential variable in the process; moreover, it is noteworthy that for companies that have maintained the accounting restatement practices, the cost versus the benefit of the adjusted information is neither altered nor relevant because, according to the interviewees, this practice was already established within the system.

- H2-env: (+) Events emerging in the organizational field - These results indicate that the levels of inflation during the period and the emergence of new regulations for the sectors were influential in the process of deinstitutionalizing the indexation practices in Brazilian companies. However, the distribution of the company results to the shareholders was not a representative variable. These results were confirmed in the interviews.

\section{- H3_org (-) Social organizational pressures [social} fragmentation (change in organizational structure); disruption of historical continuity (change of legal format of the company - IPO or delisting); and changes in institutionalized values or rules (completion of mergers, divisions or incorporations and/or changes of managers internally] - The results showed that none of the variables in this construct were considered influential, compared with the results obtained in the other constructs analyzed, based on the means obtained $(1.84,1.73,1.61$ and 1.50$)$.

- H3_env (-) Structural disaggregation in the organizational field - According to this hypothesis, the process of the international harmonization of accounting practices could influence the use of accounting restatement practices in business. The results confirm the hypothesis. These results were also confirmed in the interviews.

In this research, it can be concluded that the motivating factors for the process of deinstitutionalizing the accounting restatement practices in Brazilian companies were the following: (i) the reduction of inflation rates in the Brazilian economy; (ii) the changes in laws regarding the publication of adjusted financial information; (iii) the financial markets no longer requiring this type of information; (iv) the maintenance costs associated with the practice outweighing the benefits of the information generated; (v) the emergence of new financial technologies; (vi) the levels of inflation during the period (month and year); and (vii) the international harmonization of accounting practices.
Therefore, regarding the evaluation of the constructs, it is important to highlight the political pressures (environmental level) and the functional pressures in both dimensions (organizational and environmental). Social pressures, however, were not shown to be significant.

The relevance of the adjusted information in the Brazilian market for accounting managers agrees with the results of the research conducted in the US and UK markets (Heintz, 1973; Enis, 1988; Pong \& Whittington, 1996; Perrow, 1986; Nobes, 1991). Those surveys were conducted under inflationary scenarios equivalent to the Brazilian market, where inflation was also in a decline phase, i.e., there were low levels of inflation in the economy. Those studies analyzed the following: a) the qualitative characteristics of information, or the usefulness of the information for users (Heintz, 1973; Enis, 1988); b) the costs of calculating this type of information (Watts \& Zimmerman, 1980); c) the influence of external agents (Pong \& Whittington, 1996); d) the levels of enforcement and publication obligations (Perrow, 1986); and e) the process of international harmonization of accounting and the emergence of new practices (Pong \& Whittington, 1996; Nobes, 1991). The authors found that the market attaches little relevance to the adjusted information; that is, the maintenance of the restatement practices is related to their utility.

The study limitations include the fact that the results do not permit generalizations because the sample is not probabilistic. Moreover, the results obtained in the process of deinstitutionalization result from information that only reflected the perceptions of accountants and controllers. It is noteworthy that the study was conducted during a distinct period that did not necessarily coincide with the exact time of deinstitutionalization. Data collection on the abandonment process occurred through the use of questionnaires, developed from the framework of institutional theory. The relevance (importance and influence) of the variables and the constructs was measured by means of a semantic scale (a Likert scale).

The following suggestions are made for future research: establish whether the factors highlighted by the accountants and controllers differ significantly from those indicated by other stakeholders; verify that the use of the adjusted information impacts the decisions of sophisticated investors; and evaluate how the users interpret the inflation-adjusted financial information and whether it influences their predictions, investments and other company decisions (choices).

\section{References}

Arthur Young \& Company. (1982, January). Usefulness of inflationadjusted reporting. The CPA Journal, 8-9.

Baran, Lakonishok, \& Ofer, R. (1980, Spring). The vahte of general price level adjusted data to bond rating. Journal of Business Finance and Accounting, 135-149.

Beaver, W. H. (1998). Financial reporting: an accounting revolution. (3rd ed). New Jersey: Prentice Hall.

Beaver, W. H., Gritfin, P. A., \& Landsman, W. R. (1982). The incremental information content of replacement cost earnings. Journal of Accounting and Economics, 4, 15-39.
Beaver, W. H., \& Landsman, W. R. (1983). Incremental information content of statement 33 disclosures. Stamford, CT: FASB.

Becker, M. C. (2004). Organizational routines: a review of the literature. Industrial and Corporate Change, 13, 643-677.

Bido, D. (2009). Análise fatorial exploratória: curiosidades e dicas. Recuperado em 10 abril, 2009, de http://groups.google.com.br/group/ fatorial.

Brayshaw, R. E., \& Miro, A. R. O. (1985, Summer). The information content of inflation-adjusted financial statements. Journal of Business Finance and Accounting, 249-261. 
Bublitz, B., Frecka, T. J., \& Mckeown, J. C. (1985). Market association tests and FASB Statement n. 33 disclosures: a reexamination. Journal of Accounting Research, Supplement, 1-27.

Cardoso, F. C. (2009). 15 anos de Plano Real. Programa Roda Viva. Entrevista concedida à televisão TVCULTURA em 23 de março de 2009. Recuperado de http://www.tvcultura.com.br/rodaviva/ programa/pgm1146.

Carruthers, B. G. (1995, May). Accounting, ambiguity, and the new institutionalism. Accounting, Organizations And Society, 20 (4), 313328.

Chua, W. F.(1986, October). Radical developments in accounting thought. The Accounting Review, 61 (4), 601-632.

Collier, P. M. (2005). Entrepreneurial control and the construction of a relevant accounting. Management Accounting Research, 16, 321-339.

Cornick, M. F. (1982, January). What information do bankers want from inflation accounting? The Journal of Commercial Bank Lfflding, 56-65.

Craft, J. A. (1981). Information disclosure and the role of the accountant in collective bargaining. Accounting Organizations and Society, $97-$ 107.

Davidson, S., Sticckney, C. P., \& Weil, R. L. Financial accounting. (5th ed.) Chicago: Dryden Press.

Dimaggio, P. J., \& Powell, W. W. (1983, April). The iron cage revisited: institutional isomorphism and collective rationality in organizational fields. American Sociological Review, 48 (2), 147-160.

Dyckman, T. (1969). Investment analysis and general price-level adjustments. Studies in Accounting Research, Sarasota, FL, American Accounting Association, 1.

Enis, C. R. (1988). The impact of current valued data on the predictive judgments of investors. Accounting, Organizations and Society, 123145

Famá, R. (1980). Retorno sobre o investimento: sua utilização no Brasil, face à inflação e à evolução da legislação sobre a correção monetária nos demonstrativos financeiros. Dissertação de mestrado, Faculdade de Economia, Administração e Contabilidade, Universidade de São Paulo, São Paulo, SP, Brasil.

Ferreira, A., \& Otley, D. (2005). The design and use of management control systems: an extended framework for analysis. Social Science Research Network

Fields, T. D., Lys, T. Z., \& Vincent, L. (2001, September). Empirical research on accounting choice. Journal of Accounting and Economics, 31 (1-3), 255-307.

Financial Accounting Standards Board, Statement of Financial Accounting Standards Number 33. (1979). Financial Reporting and Changing Prices, Stamford, CT: FASB.

Fipecafi. Fundação Instituto de Pesquisas Contábeis, Atuariais e Financeiras. (1995-2009). Banco de dados da Revista Exame Melhores e Maiores.

Flesher, D. L., \& Soroosh, J. (1983, January). Controllers Say FASB 33 is not very useful. Management Accounting, 50-53.

Foley, B. J., \& Maunders, T. (1977). Accounting information disclosure and collective bargaining. New York: MacMillian.

Fornell, C., Johnson, M. D., Anderson, E. W., Cha, J., \& Bryant, B. E. (1996, October). The American customer satisfaction index: nature, purpose, and findings. Journal of Marketing, 60, 7-18.

Friedland, R., \& Alford, R. R. (1991). Bringing society back. In Walter, W., \& Powell; Paul J. DiMaggio (Eds.). Symbols, practices, and institutional contradictions. The new institutionalism in organizational analysis. Chicago: University of Chicago Press.

Frishkoff, P. (1982). Financial Reporting and Changing Prices, A Review of Empirical Research, Stamford, CT: FASB.

González, P. (1999). Revisão crítica do sistema de correção monetária vigente na Colômbia sob uma perspectiva da técnica desenvolvida no Brasil. Dissertação de mestrado, Faculdade de Economia e Administração, Universidade de São Paulo, São Paulo, SP, Brasil.

Graeff, J. F. (2005). Pressões ambientais e respostas estratégicas na institucionalização no plantio direto no Paraná. Dissertação de mestrado, Setor de Ciências Sociais e Aplicadas da Universidade Federal do Paraná, Universidade Federal do Paraná, Curitiba, PR, Brasil.

Greenwood, R., Suddaby, R., \& Hinings, C. R. (2002). Theorizing change: the role of professional associations in the transformation of institutionalized fields. Academy of Management Journal, 45, 58-80.

Hair, J. F., Anderson, R. E., Tatham, R. L., \& Black, W. C. (2005). Análise multivariada de dados. (5. ed.) Porto Alegre: Bookman.

Heintz, J. A. (1973, October). Price-level restated financial statements and investment decision making. The Accounting Review, 679-689.
Hodgson, G., \& Knudsen, T. (2004). The firm as an interactor: firms as vehicles for habits and routines. Journal of Evolutionary Economics, 14. (3), 281-307.

Hoffman, A. J. (1999). Institutional evolution and change: environmentalism and the U.S. chemical industry. Academy of Management Journal, 42, 351-371.

Istvan, D. F., \& Avery, C. G. (1979). Accounting principles. New York: Harcourt Brace Jovanovich

Johansson, T., \& Siverbo, S. (2009). Why is research on management accounting change not explicitly evolutionary? Taking the next step in the conceptualisation of management accounting change. Management Accounting Research, 20, 146-162.

Kury, K. W. (2007). Decoupled earnings: an institutional perspective of consequences of maximizing shareholder value. Accounting Forum, 31 (4), $370-383$.

Lukka, K. (2007). Management accounting change and stability: loosely coupled rules and routines in action. Management Accounting Research, 18, 76-101.

Lustgarten, S. (1982). The impact of replacement cost disclosure on security prices. Journal of Accounting and Economics, 4, 121-141.

Machado-da-Silva, C. L., Fonseca, V. S. da, \& Crubellate, J. M. (2005). Estrutura, agência e interpretação: elementos para uma abordagem recursiva do processo de institucionalização. Revista de Administração Contemporânea, 9, 9-39.

Maroco, J. (2003). Análise estatística com utilização do SPSS. Lisboa: Sílabo.

Martinez, A. L. (2001). Custo de oportunidade, custo de capital, juros sobre o capital próprio, EVA e MVA. In Martins, E. (Org.). Avaliação de empresas: da mensuração contábil à econômica. São Paulo: Atlas, pp. 186-262.

Matias, J. R. (1972). Correção monetária. Rio de Janeiro: Expressão e Cultura.

Matolcsy, P. (1984, Autumn). Evidence on the joint and marginal information content of inflation-adjusted accounting income numbers. Journal of Accounting Research, 555-569.

Mautz, JR. R. D. (1990). Inflation-adjusted disclosures and the determination of ability to pay in collective bargaining. Accounting Organizations and Society, 15 (4), 273-295.

Mccaslin, T. E., \& Stanga, K. G. (1982, September). How preparers assess constant dollar in current cost information. NationaI Public Accountant, 31-35.

Mcintyre. E. V. (1973, July). Current-cost financial statements and common-stock investments decisions. The Accounting Review, 575-585.

Meyer, J. W., \& Rowan, B. (1991). Institutionalized organizations: formal structure as myth and ceremony. In Powell, W. W., \& Dimaggio, P. J. The new institutionalism in organizational analysis. Chicago: University of Chicago Press.

Miller, P. (1992). Accounting and objectivity: the invention of calculating selves and calculable spaces. Annals of Scholarship, 61-86.

Niyama, J. K. (2005). Contabilidade internacional. São Paulo: Atlas.

Nobes, C. (1991, Summer). Cycles in UK Standard Setting. Accounting and Business Research.

Oliver, C. (1991). Strategic responses to institutional processes. Academy of Management Review, 16, 145-179.

Oliver C. (1992). The antecedents of desinstitutionalization. Organization Studies, 13 (4), 563-588.

Olsen, C. (1985). Valuation implications of SFAS n. 33 data for electric utility investors. Journal of Accounting Research, (Supplement), 28-53.

Owen, D.L., \& Lloyd, A. J. (1985). The use of financial information by trade union negotiators in plant level collective bargaining. Accounting, Organizations and Society, 329-350.

Palmer, J. R. (1977). The use of accounting information in labor negotiations. New York: National Association of Accountants.

Perrow, C. (1986). Complex organizations: a critical essay. New York: Random House.

Pillsbury, W. F. (1958, June). Organized labor's views of corporate financial information, Journal of Accountancy, 46-56.

Pong, C. K. M., \& Whittington, G. (1996). The withdrawal of current cost accounting in the United Kingdom: a study of the accounting standards committee. Abacus, 32 (1), 30-53.

Ponte, V. M. R., Oliveira, M. C., Moura, H., \& Carmo, R. C. de A. (2007, September-December). Análise das práticas de evidenciação de informações obrigatórias, não-obrigatórias e avançadas nas demonstrações contábeis das sociedades anônimas no Brasil: um estudo comparativo dos exercícios de 2002 e 2005. Revista 
Contabilidade \& Finanças, 18 (45), 50-62.

Puxty, A. G. (1997). Accounting choice and a theory of crisis. Accounting, Organizations and Society, 22 (7), 713-735.

Richardson, A. J. (1987). Accounting as a legitimating institution. Accounting Organizations and Society, 12 (4), 341-355.

Rodrik, D., \& Subramanian, A. (2003, June). the primacy of institutions. Finance and Development, 31-34.

Scapens, R. W. (2006). Understanding management accounting practices: a personal journey. The British Accounting Review, 38, 1-30.

Schaefer, T. F. (1984, Autumn). The information content of current cost income relative to dividends and historical cost income. Journal of Accounting Research, 647-656.

Scott, W. R. (2001). Institutions and organizations: ideas and interests. Los Angeles: Sage Publications.

Seed, A. H. (1978, July). III, inflation - its impact on financial reporting and decision-making. Financial Executives Institute, 38-46.

Seo, M.-G., \& Creed, W. E. D. (2002). Institutional contradictions, praxis, and institutional change: a dialectical perspective. Acad. Manage. Rev. 27 (2), 222-247.

Simons, R. (1995). Levers of control: how managers use innovative control systems to drive strategic renewal. Harvard Business School Press.
Suchman, M. (1995). Managing legitimacy: strategic and institutional approaches. Academy of Management Review, 20, 571-611.

Tenenhaus, M., Vinzi, V. E., Chatelin, Y., \& Lauro, C. (2005). PLS path modeling. Computational Statistics \& Data Analysis, 48, 159-205.

Vasconcelos, F. C. de. (2007). Dinâmica organizacional e estratégia: imagens e conceitos. São Paulo: Pioneira Thomson Learning.

Venard, B., \& Hanafi, M. (2007). Organizational isomorphism and corruption in financial institutions: empirical research in emerging countries. Journal of Business Ethics, 81, 481-498.

Watts, R. L.; Zimmerman, J. L. (1980). On the irrelevance of replacement cost disclosures for security prices. Journal of Accounting and Economics, 2, 95-106.

Yates, J. (1989). Control through communication: the rise of system in American management. Baltimore: Johns Hopkins University Press.

Zucker, L. G. (1991). The role of institutionalization in cultural persistence. In Dimaggio, P. J., \& Powell, W. W (Eds.). The new institutionalism in organizational analysis. Chicago: The University of Chicago Press, pp. 83-107. 